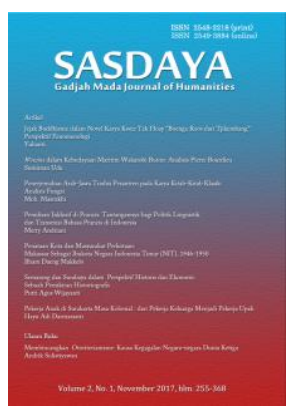

Unit Penelitian dan Penerbitan

Fakultas Ilmu Budaya,

Universitas Gadjah Mada

SASDAYA,

Gadjah Mada Journal of Humanities

ISSN: 2548-3218 (print); ISSN : 2549-3884 (online); website: https://jurnal.ugm.ac.id/sasdayajournal/index

2 Penerjemahan Arab-Jawa Tradisi Pesantren Pada Karya Kitab-Kitab Klasik: Analisis Fungsi

2. Arabic-Javanese Translations on Classical Books in Pesantren Tradition: Function Analysis

2os Penulis/Author(s) : Moh. Masrukhi

2 Sumber/Source: SASDAYA, Gadjah Mada Journal of Humanities, Vol. 2, No. 1 (November 2017), pp. 283-301

es DOI:

- Penerbit : Unit Penelitian dan Publikasi Fakultas Ilmu Budaya Universitas Gadjah Mada, Indonesia 


\title{
PENERJEMAHAN ARAB-JAWA TRADISI PESANTREN PADA KARYA KITAB-KITAB KLASIK: ANALISIS FUNGSI
}

\author{
Moh. Masrukhi ${ }^{1}$
}

\begin{abstract}
The aims of education in Javanese pesantren is generally to transmit the teachings of Islam. Its teaching system to this day still refers to the Arabic classic books alkutubul-mu tabara (KKbA). In order for $\mathrm{KKbA}$ to be understood by the general public, there is an effort to translate it into Javanese language by translating the pesantren model or tradition (PTP). The typical translation of Pesantren is done per word according to the order in the source language (BSu) or the Arabic language. The apparent feature of the translation results is the addition of markers to the grammatical unit functions of the source language in the target language (BSa), like Javanese language. The theory used in this research is the Arabic syntax theory which is already well known and written by Arabic linguists. The result of the research about the marker of the grammatical unit function in $\mathrm{KKbA}$ is divided into four parts. This division is done to show the uniqueness of the structure owned by Arabic language. The division includes: a) marker of mubtada ' and khabar function; b) the marker of the functions of $f \bar{a}^{\prime} i l$ and nāib $\left.f \bar{a}^{\prime} i l, c\right)$ the syntactic function marker of $m a f^{\prime} \bar{u} l$ bih; and $\mathrm{d}$ ) the marker of an explanatory function, such as maf' $\bar{u} l$ fihh, maf' $\bar{u} l$ mutlaq, maf'ūl li ajlihi, hāl, and tamyizz. Thus, this tradition of interpretation of Pesantren in addition to acquiring knowledge of $\mathrm{KKbA}$ studied, as well as get knowledge about Arabic grammar.
\end{abstract}

Keywords: pesantren traditions of translations, marker, function, and grammatical unit.

\section{PENDAHULUAN}

Pesantren dianggap sebagai sebuah tradisi agung 'great tradition' di Indonesia yang salah satu tujuan pendidikannya adalah mentransmisikan ajaran agama Islam melalui kitab-kitab klasik (al-kutubul-mu'tabarah) berbahasa Arab (KKbA). Tradisi pesantren umumnya bernafaskan sufistik dan 'ubudiyah 'akidah dan peribadatan' (van Bruinessen, 1999:17-22). Pengajaran yang berkaitan dengan 'ubudiyah inilah yang sampai sekarang masih dilakukan oleh kebanyakan pesantren, baik di Jawa maupun di luar Jawa.

${ }^{1}$ Dosen Pada Fakultas Ilmu Budaya Universitas Gadjah Mada, Yogyakarta, Email: moh_masruhi@yahoo.com 
Untuk memahami isi kitab-kitab klasik ini kemudian ada upaya penerjemahannya ke dalam bahasa daerah, salah satunya adalah bahasa Jawa khas pesantren (Masrukhi, 2003:1). Melalui karya-karya terjemahan inilah seseorang memperoleh berbagai ilmu pengetahuan, ilmu agama, dan sebagainya.

Dalam kegiatan penerjemahan penguasaan bahasa sumber (BSu) dan bahasa sasaran (BSa) merupakan syarat utama yang harus dipenuhi oleh seorang penerjemah. Penguasaan kedua bahasa tersebut harus pada tingkatan memahami dengan baik aturan atau kaidah BSu kemudian menransfer isinya sesuai dengan aturan-aturan atau kaidah yang ada pada BSa. Catford (Yusuf, 1994:9) dalam bukunya A Linguistic Theory of Translation mengatakan bahwa menerjemahkan itu adalah '... the replacement of textual material in one language by equivalent textual material in another' atau menerjemahkan adalah mengalihkan teks suatu bahasa ke dalam bahasa yang lain secara padu padan.

Dari ungkapan Catford di atas dapat dipahami pula bahwa untuk menguasai bahasa lain selain bahasa ibu banyak hal yang harus diikuti dan ini seringkali mengalami kendala. Dalam hal ini struktur bahasa Arab (bA) akan berbeda dengan struktur bahasa Jawa (bJ). Perbedaan itu misalnya antara lain, adanya kelas kata, derivasi, kala, gender, fungsi, kategori, dan peran kata dalam tata kalimat kedua bahasa tersebut. Itulah cerminan perbedaan struktur sebagai hasil dari dua kultur yang berlainan. Dengan demikian bagi orang yang ingin menerjemahkan bahasa Arab dengan cara khas pesantren ini harus tahu seluk beluk bahasa Arab.

Proses penerjemahan oleh santri itu biasanya disebut ngesahi/maknani 'memberi tanda baca/memberi arti'. Ngesahi 'menerjemahkan' setiap kata Arab

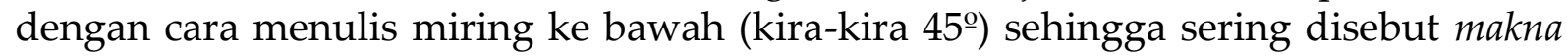
gandhul 'terjemah menggantung' atau makna jenggot 'menjulur seperti jenggot'. Terjemahan perkata tersebut menggunakan aksara Arab Pegon (bJ, tapi dengan aksara Arab) (Masrukhi, 2003:38). Bahasa Jawa yang digunakan dalam penerjemahan pun juga khas pesantren dan urut perkata sesuai urutan struktur BSu atau bA. Penerjemahan dan penulisan tersebut dapat diperhatikan pada contoh berikut.

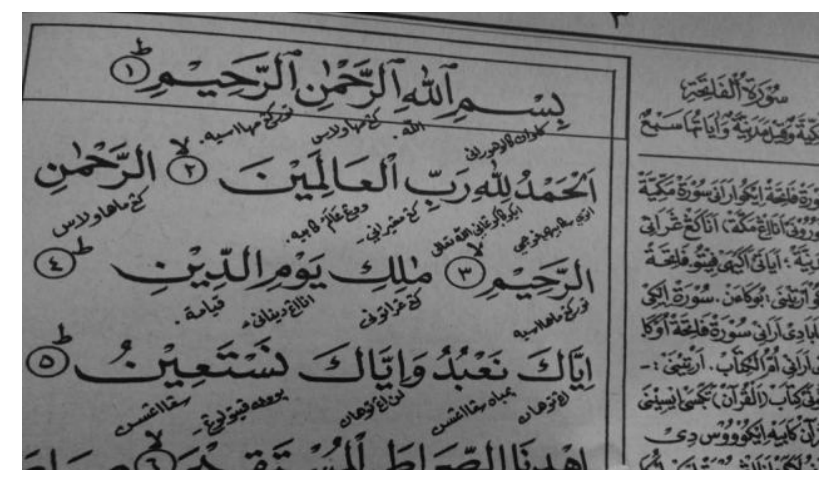

Jika diperhatikan contoh di atas, ciri-ciri yang tampak adalah adanya penambahan pemarkah gramatika pada BSa, seperti utawi, $i k u, k a n g$, dan sebagainya. Pemarkah gramatika yang dimaksud di sini adalah pemarkah satuan kebahasaan yang menunjukkan kelas atau fungsi kata tersebut dalam bahasa Arab. Pemarkahan 
fungsi satuan kebahasaan tersebut dapat diperhatikan sebagaimana hasil terjemahan ayat berikut.

$$
\text { الحمد الله رب العالمين }
$$
a) [alhamdu lillāhi rabbil ‘ālamìna]
b) /Al-hamdu utawi sekabehe puji/iku lillāhi kagungane Allah/rabbil 'älamina kang mengerani wong ngalam kabeh/
c) 'Segala puji bagi Allah, Tuhan seru sekalian alam' (QS, 1:1)

Proses penerjemahan ayat di atas dilakukan dengan cara berurutan kata perkata. Setiap kata diterjemahkan ke dalam bahasa sasaran (BSa), yaitu bahasa Jawa sekaligus fungsi kata tersebut dalam kalimat bahasa Arab, seperti contoh (b) dengan pemarkah tertentu dalam bJ. Dengan demikian santri selain dapat belajar arti per kata kitab-kitab yang sedang dibaca, sekaligus mereka belajar pula gramatika bA langsung dari kitb-kitab tersebut (Dhofir, 1984:28).

Penerjemahan model atau tradisi khas pesantren (PTP) seperti ini dapat ditemukan pada kitab-kitab keagamaan, seperti Tafsir Al-Ibriz yang ditulis oleh K.H. Bisyri Musthafa.

Dari uraian tersebut maka timbul pertanyaan bagaimana penerjemahan fungsi-fungsi gramatika tersebut dalam PTP. Pemarkah apa sajakah yang digunakan untuk masing-masing fungsi gramatika bahasa Arab tersebut dalam terjemahan kitab tafsir Al-Ibris juz 1 karya Bisyri Mustafa.

\section{TUJUAN PENELITIAN}

Penelitian pemarkah gramatika penerjemahan Arab-Jawa ini bertujuan untuk mendapat gambaran tentang pemarkah fungsi gramatika pada penerjemahan ArabJawa khas pesantren ini. Di samping itu juga diharapkan dapat memberikan pemahaman yang konkret terhadap gramatika Arab bagi para pembaca teks-teks Arab, khususnya kitab-kitab klasik di pesantren.

\section{LANDASAN TEORI}

Penerjemahan biasa diartikan sebagai proses pengalihan pesan dari suatu bahasa (BSu) ke bahasa yang lain (BSa). Ad-Darubi (1994:61) mengatakan bahwa

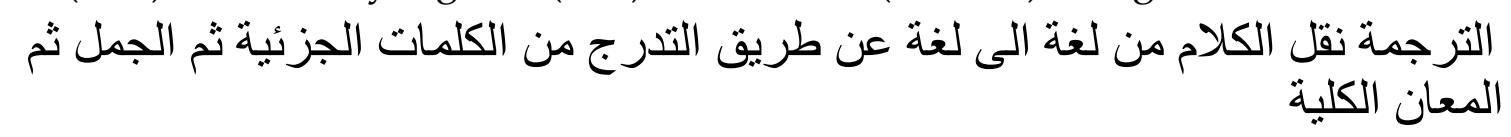

"Penerjemahan adalah mentransfer al-kalam dari satu bahasa ke bahasa yang lain secara bertahap dari bagain-bagian kata, kalimat, dan arti secara keseluruhan" 
Sejalan dengan Ad-Darubi di atas Nida (dalam Drewes, 1997:84) berpendapat bahwa dalam proses penerjemahan paling tidak ada tiga tahapan yang diperlukan, yaitu: a) analisis makna yang terdiri atas analisis tata bahasa atau grammar, analisis makna kata, dan anlisis kombinasi kata (kolokasi) bahasa sumber (BSu); b) pemindahan ke dalam bahasa sasaran (BSa); c) penyusunan kembali teks secara menyeluruh sehingga dapat dipahami pembaca.

Dari dua pendapat yang sama tersebut di atas kiranya dapat dipahami bahwa penerjemahan dari satu teks bahasa ke dalam bahasa yang lain itu dilakukan dengan tahapan-tahapan mulai dari satuan semantis pada tataran kata, frase, kalimat, dan yang terakhir adalah penerjemahan secara keseluruhan, yaitu pada tataran wacana. Tahapan-tahapan tersebut gunanya untuk memahami secara baik makna kata yang kadang baru bisa dipahami maknanya setelah memperhatikan lingkungan yang lain, seperti frasa, klausa, ataupun kalimat. Ekspresi-ekspresi kebahasaan penutur BSu sangat mungkin berbeda dengan ekspresi kebahasaan penutur BSa. Ekspresi tersebut juga ditata dalam tata bahasa mereka. Dari tahapan-tahapan yang dilakukan itu, maka akan dapat dipahami apakah ekspresi yang disampaikan tersebut merupakan ekspresi struktural ataukah ekspresi idiomatik.

\section{PEMBAHASAN}

Pembahasan dalam penelitian pemarkah gramatika penerjemahan Arab-Jawa ini mengarah pada penerjemahan fungsi-fungsi sintaksis bahasa Arab. Seperti diketahui bahwa struktur kalimat bahasa Arab (bA) terdiri atas 2 struktur. Pertama, struktur al-jumlah al-ismiyah (struktur kalimat yang diawali dengan ism 'nomina'). Struktur ini terdiri atas fungtor atau fungsi (Asrori, 2004:74), yaitu mubtada' 'subjek/pelaku' (S) dan khabar 'predikat' (P). Kedua, struktur kalimat yang diawali dengan fi'l (verba) atau al-jumlah al-fi'liyah yang terdiri atas fi'l 'predikat' (P), fá'il 'subjek/pelaku' (S), maf ūl bih 'objek' (O), dan/atau Keterangan (Ket.). Dengan demikian pemarkah-pemarkah yang digunakan dalam penerjemahan kalimatkalimat tersebut adalah pemarkah pada fungsi-fungsi S, P, O, dan Ket.

Pembahasan mengenai pemarkah fungsi sintaksis ini dibagi dalam empat bagian. Pembagian ini dilakukan untuk menunjukkan kekhasan struktur yang dimiliki bA. Pembagian tersebut meliputi: a) pemarkah fungsi mubtada' dan khabar; b) pemarkah fungsi $f \bar{a}^{\prime} i l$ dan $n \bar{a} i b f \bar{a}^{\prime} i l$, sedangkan pembahasan tentang $f i^{\prime} l$ tidak akan dibahas pada tataran ini karena fi'l merupakan bagian dari kelas kata dalam bA; c) pemarkah fungsi sintaksis maf'ül bih; dan d) pemarkah fungsi keterangan, seperti maf' $\bar{u}$ f fìh, maf' $\bar{u} l$ mutlaq, maf'ūl li ajlihi, hal, dan tamyiz.

\section{A. Pemarkah Fungsi Gramatika pada Kalimat Nominal}

Struktur kalimat nominal dalam bahasa Arab terdiri atas mubtada' 'subjek' (Rajihi, 2011:87) dan khabar 'predikat' (Rajihi, 2011:98). Pemarkah fungsi sintaksis yang biasa digunakan dalam penerjemahan tradisi pesantren pada kalimat nominal al-jumlah al-ismiyah ada dua macam, yaitu kata utawi sebagai pemarkah fungsi mubtada' dan iku untuk pemarkah fungsi khabar. 
Mubtada' adalah ism (nomina) dalam kasus rafa' (nominatif) sebagai pokok kalimat yang biasanya diletakkan di awal kalimat. Khabar adalah ism (nomina) juga dalam kasus rafa' (nominatif) yang menjelaskan mubtada'. Khabar umumnya diletakkan sesudah mubtada' (Dahdah, 1992:135).

\section{Pemarkah Fungsi Mubtada' (subjek) 'utawi'}

Mubtada' 'subjek' adalah nomina yang menempati posisi awal pada suatu kalimat bA (Dahdah, 1999:161). Nomina ini menurut Rajihi (2011:87) adalah nomina dan pronomina yang mandiri selamanya dan harus sharīh 'sudah jelas'. Dia selalu dibaca rafa' atau berkasus nominatif. Dalam terjemahan pesantren, umumnya kata utawi ini mendahului kata Arabnya sebagaimana pada ayat-ayat berikut.

1.

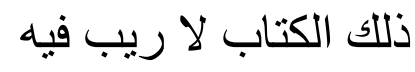

[dzālikal kitābu lā raiba fìh]

/dzālika utawi iki/al-kitābu kitab/iku lā raiba ora ana kemamangan

iku maujud/fìhi ing dalem kitab/

'Kitab al-Qur'an itu tidak ada keraguan di dalamnya' (QS 2:2)

2.

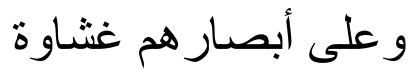

[wa 'alā abshārihim ghisyawatun]

/wa `alā abshārihim lan iku tetep ing atase pira-pira peningale al-

ladzina/ghisyāwah utawi ana tutup/

'Dan penglihatan mereka tertutup' (QS 2:7)

Dari data tersebut di atas yang mesti diperhatikan adalah kata utawi pada kalimat contoh (1) menandai fungsi mubtada' yang berada pada awal kalimat, sedangkan pada kalimat (2) fungsi mubtada' berada di akhir kalimat karena kalimat tersebut fungsi mubtada' didahului oleh fungsi khabar. Di dalam al-Qur'an surat al-Baqarah ini ada ayat lain yang struktur kalimatnya menggunakan pronomina, akan tetapi tidak penggunaan pemarkah utawi. Kalimat (ayat) tersebut adalah:

3. أولئك هم الخاسرون

[fa'ulā'ika humul khāsirūn]

/fa'ula'ika utawi mengkono-mengkono alladzinna"/hum iya

('ulā'ika)/iku al-khāsirūna wong kang padha tuna kabeh/

'... maka mereka itulah orang-orang yang merugi' (QS 2:27)

Pronomina persona hum pada kalimat (2) di atas tidak diikuti kata utawi. Pronomina persona hum pada kalimat (2) merupakan mubtada' tsāni setelah mubtada' awal, yaitu pronomina demonstratifa $u \overline{l a}^{\prime} i k a$. Pronomina hum pada kalimat tersebut merupakan pronomina persona yang digunakan untuk menyambungkan pengertian 'dlamir fashl' (Rajihi, 2011:47) atau dimaksudkan untuk menjelaskan kata sebelumnya. Pronomina semacam ini dalam sintaksis bA tidak memiliki kedudukan dalam kasus 
i rab, melainkan untuk mengantarai antara mubtada' dan sifatnya. Oleh karena itu, pronomina jamak hum dalam kalimat tersebut tidak diterjemahkan dengan penegas utawi, melainkan digunakan kata tugas yang menandai pemastian (Sudaryanto, 1991:122), yaitu kata 'iya'. Namun, di sisi lain menurut Rajihi (2011:48) hal ini bisa saja dipandang sebagaimana pronomina yang mandiri dan menduduki posisi mubtada', seperti kalimat di bawah:

4 .

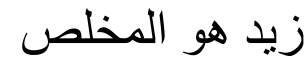

[zaidun huwa al-mukhlish]

/zaidun utawi Zaid/huwa utawi Zaid/iku al-mukhlishu wong

kang ikhlas/'Zaid (laki-laki) yang ikhlas'

Dari kalimat contoh tersebut dapat dikatakan bahwa pronomina huwa 'dia (laki-laki)' berkedudukan sebagai mubtada' 'subjek' kedua yang terletak setelah nama diri Zaid 'Zaid'.

\section{Pemarkah Fungsi Khabar (predikat) ' $i k u$ '}

Khabar adalah ism 'nomina' yang menjelaskan mubtada' agar suatu kalimat menjadi sempurna atau jelas (Rajihi, 2011:98) dan berterima. Karena sebagai nomina yang bersandar dan bergantung kepada mubtada', maka nomina ini i'rab 'kasus'nya disyaratkan juga sama dengan mubtada', yaitu kasus nominatif. Posisi predikat 'khabar' sebagaimana juga struktur sintaksis bahasa Indonesia dan bahasa Jawa, dalam bahasa Arab juga terletak sesudah subjek atau mubtada'. Dalam penerjemahan tradisi pesantren fungsi predikat ini didahului pronomina demonstratifa substantif íku (Sudaryanto, 1991:94). Berikut contoh ayat-ayat yang mengandung khabar dan penerjemahannya:

5.

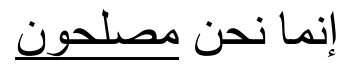

[inna mā nahnu muslihūn]

/innamā anging mesthine/nahnu utawi ingsun/iku mushlihūna gawe becik kabeh/

'... sesungguhnya hanyalah kami orang-orang yang berbuat baik' (QS 2:11)

6.

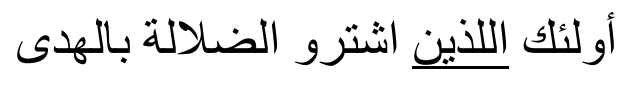

[ulāikalladzinasytarawudldlālata bilhudā]

/ulā'ika utawi mengkono-mengkono munafiqin/alladzina iku

wong-wong/isytarawu kang ngijoli iya munafiqin"/adl-dlalālata

ing sasar/bil-hudā diijoli kelawan pituduh/

'Mereka itulah orang-orang yang membeli kesesatan dengan petunjuk (kebenaran)' (QS 2:16) 
Nomina-nomina yang digarisbawahi pada kalimat di atas merupakan predikat atau khabar. Fungsi predikat pada dua kalimat tersebut penerjemahannya ditandai dengan menggunakan pronomina demonstratifa substantif bJ $i k u$. Namun, adakalanya fungsi khabar ini pada kondisi tertentu menempati posisi yang berbeda, yaitu terletak di depan mubtada' dengan ketentuan bahwa mubtada' 'subjek'nya berbentuk nakirah 'taktakrif', sebagaimana contoh berikut.

7.

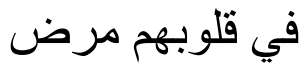

[fï qulūbihim maradlun]

/iku fì qulūbihim tetep ingdalem pira-pira atine man/maradlun

utawi lara/ 'Hati-hati mereka itu sakit' (QS, 2:10)

Frasa preposisional fì qulübihim pada contoh (6) di atas merupakan permulaan ayat. Penerjemahan frasa preposisional fì qulübihim ini dalam tradisi pesantren digunakan (bJ) $i k u$. Pronomina demonstratifa sunstantif $i k u$ digunakan untuk menerjemahkan susunan tersebut karena frase tersebut merupakan khabar muqaddam atau predikat yang harus diletakan di awal kalimat. Pengedepanan semacam ini di dalam bahasa Arab wajib hukumnya. Fungsi khabar berada di depan (mubtada') karena kategori mubtada'nya adalah taktakrif 'nakirah' (Rajihi, 2011:108-110, Ghulayaini, 2005, 2:379).

Penggunaan pronomina demonstratifa substantive BJ 'iku' juga digunakan pada

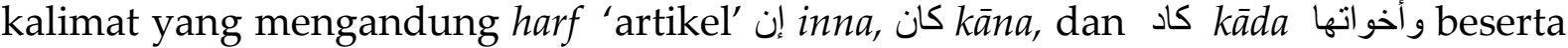
kawan-kawanya yang juga memiliki khabar. Pemarkah fungsi khabar atau predikat tersebut akan muncul pula sebagai berikut.

8.

إنك أنت العليم الحكيح

[innaka antal 'alìmul hakìm]

/innaka setuhune panjenengan/anta inggih panjenengan/iku al alìmu kang ngudaneni/al hakīmu tur kang wicaksana/

'Sesungguhnya Engkaulah Yang Maha Mengetahui dan Maha Bijaksana' (QS 2:32)

9.

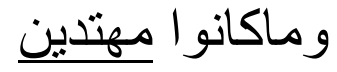

[ wa mā kānu muhtadīn]

Iwa mā kānu lan ora ana sapa wong munafik/iku muhtadīn

Oleh pituduh abeh/ 'dan orang-orang munafik itu tidak mendapatkan petunjuk' (QS 2:16)

Artikel inna, kāna dan kāda beserta kawan-kawannya masuk pada kategori jumlah ismiyah atau kalimat nominal. Penggunaan artikel-artikel tersebut dalam kalimat memiliki implikasi dan pengaruh terhadap nomina-nomina sesudahnya, yaitu pada mubtada' dan khabar, Inna dan kawan-kawannya mengakibatkan mubtada' menjadi manshūb 'kasus akusatif' yang disebut sebagai ism inna, sedangkan predikat khabarnya menjadi marfu' 'kasus nominatif' yang disebut sebagai khabar inna (Rajihi, 2011:141) sebagaimana pada contoh (8) pada nomina yang diberi garis bawah. 
Sementara itu, kana dan kada beserta kawan-kawannya 'its sisters' (Dahdah, 1991:152), dalam kalimat mempengaruhi fungsi mubtada'nya atau subjeknya menjadi nominative. Fungsi subjek ini disebut sebagai ism (kāna dan kāala), sedangkan khabarnya dinashabkan 'kasus akusatif' dan disebut sebagai khabar kāna atau khabar $k \bar{a} d a$ (Rajihi, 2011:113) sebagaimana kata yang digaris bawah pada contoh (9) di atas.

\section{B. Pemarkah Fungsi Gramatika pada Kalimat Verbal}

Struktur al-jumlah al-fi 'iyah 'kalimat verbal' dalam bahasa Arab terdiri atas fi' 'verba/predikat', fā'il 'pelaku/subjek' (al-Makarim, 2006:30) atau náa'ibul fāìl 'pengganti pelaku/subjek' (Dahdah, 1999:207, Rajihi,2011:184), dan maf ūl bih 'objek' jika verbanya berupa muta 'addi 'transitif' (Rajihi,2011:189). Pemarkah fungsi sintaksis pada kalimat verbal ini dalam PTP yang ditandai secara spesifik hanya fungsi fä $i l$ dan maf $\bar{u} l$ bih saja dan verba tidak ditandai. Pemarkah fungsi sintaksis pada kalimat verbal tersebut digunakan pemarkah bahasa Jawa, yaitu pronomina interogatif sapalapa 'siapa dan apa' (Sudaryanto, 1991:104) dan preposisi ing 'di' untuk menandai fungsi objek.

\section{Pemarkah Fungsi Fā'il (pelaku/subjek) 'sapa/apa'}

$F \bar{a}$ 'il adalah ism 'nomina' yang terletak sesudah fi'l 'verba' dan yang melakukan perbuatan atau subject sentence (Rajihi, 2011:174) atau pelaku pekerjaan itu agent (Dahdah, 1992:124). Untuk menandai fungsi subjek pada kalimat verbal bahasa Arab ini adalah pronomina sapa (untuk manusia/yang berakal) atau apa (untuk barang/benda mati). Penggunaannya dapat diperhatikan pada penerjemahan ayatayat contoh berikut.

10.

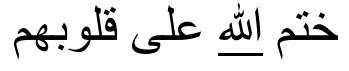

[khatamallāhu 'alā qulūbuhim]

/khatama 'wus ngelak'/sapa Allāhu 'Allah'/'alā qulūbihim iku 'tetep ingatase pira-pira atine' iya alladzinal

'Allah telah mengunci hati mereka' (QS 2:7) .

11.

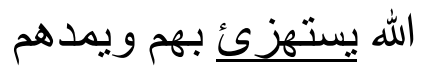

[Allāhu yastahzi'u bihim wa yamudduhum]

/Allāhu utawi Gusti Allah/iku yastahzi'u iku nggeguyu sapa Allah/ bihim kelawan munafikin/wa yamudduhum lan ngumba sapa Allah.../'Allah akan membalas olok-olokan mereka dan membiarkan mereka' (QS 2:15)

Adapun penggunaan pronomina interogatif apa digunakan pada benda-benda seperti contoh ayat berikut.

12.

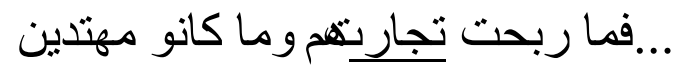

[famā rabihttijāratuhum wa mā kānu muhtadīn] 
Ifamā rabihat maka ora bathi/apa tijāratuhum dagangane munāfiqīn/wa mā kānu lan ora ana sapa munāfiqīn/iku muhtadin padha oleh pitulungan kabeh/

'...maka tidaklah beruntung perniagaan mereka dan tidaklah mendapat petunjuk' (QS, 2:16)

13.

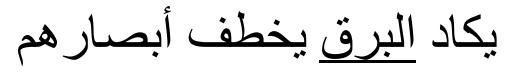

[yakādul barqu yakhthafu abshārahum]

lyakādul barqu meh-meh nyamber/apa al-barqu kilat/yakhthafu

nyamber iya barq/abshārahum ing pira-pira peningale

munāfiqin/

'Hampir-hampir kilat itu menyambar pengkihatan mereka'

(QS 2:20)

Jika diperhatikan contoh ayat-ayat di atas, pada contoh (10) nomina 'Allah' berfungsi sebagai fa il 'subjek' dan didahului oleh fi'l 'verba' khatama 'mengunci'. Pada contoh (11) yang berfungsi sebagai fa'il bukan nomina Allah lagi melainkan pronomina persona yang tersembunyi di dalam verba yastahzi'u 'nggeguyu'. Pronomina yang tersembunyi tersebut sejatinya adalah huwa 'dia' (pronomina persona ketiga) yang merujuk kepada Allah. Dengan demikian secara lengkap fungsi-fungsi yang terdapat dalam kalimat ini adalah nomina Allah sebagai mubtada', sedangkan yastahzi'u adalah khabarnya. Verba yaztahzi'u sendiri terdiri atas fi'l dan fa 'ilnya sehingga penerjemahan sapa Allah itu berada di dalam verba yastahzi'u 'Dia (Allah) menertawakan'.

Di samping itu, pronomina interogatif apa juga digunakan untuk menandai fa 'il bukan orang, tetapi untuk benda atau barang seperti pada contoh (12). Kata tijarah adalah nomina yang berfungsi sebagai pelaku dalam kalimat tersebut dan berkasus nomintaif.

Dari tampilan contoh-contoh di atas dapat disimpulkan bahwa pemarkahpemarkah yang digunakan dalam PTP, pemarkah nomina yang berakal adalah sapa dan pemarkah nomina yang tidak berakal adalah apa. Pemarkah-pemarkah tersebut termasuk pronomina interogatifa karena penggunaannya (umumnya) diletakkan sebelum pengucapan nomina dalam bahasa Arab. Kecuali apabila fā'il tersebut berupa pronomina yang tersembunyi di dalam verbanya, maka pengucapannya setelah bahasa Arabnya.

Pemarkah sapa dan apa selain digunakan pada fä̀il juga digunakan sebagai pemarkah pada $n \bar{a}^{\prime} i b u l f a \bar{~} i l$ 'pengganti fa 'il' atau pro-agent (Dahdah, 1992:125), yaitu nomina yang menempati posisi $f \bar{a}^{\prime} i l$ setelah $f a{ }^{`} i l n y a$ yang asli dibuang atau mahdzuf (Al-Makarim, 2007:117) dan verbanya berbentuk mabni majhul atau ignored verb (Dahdah, 1992:125). Misalnya:

14.

$$
\text { ولا يقبل منها شفاعة و لايؤخذ منها عدل و لا هم ينصرون }
$$

[wa lā yuqbalu minhā syafā̀tun wa lā yu'khadzu min hā 'adluun wa lā hum yunsharūna] 
Iwa lā yuqbalu lan ora diterima/minhā saking nafsun/apa syafā'atun syafaat/wa lā yu'khadzu lan ora den pundhut/apa 'adlun tebusan/wa lā hum lan ora ana utawi kaum/iku yunsharūna ditulungi kabeh sapa kaum/'(begitu pula) tidak diterima syafaat dan tebusan dari padanya, dan tidaklah mereka akan ditolong' (QS 2:48)

Jika diperhatikan pada contoh (14) di atas ada 3 kalimat verbal yang naib دa dan شفاعة atau pronomina yang tersembunyi pada verba ينصرون, yaitu hum (Jamak Mudzakkar Salim/JMS). Nomina-nomina tersebut terletak sesudah verba pasif yuqbalu 'diterima' dan yu'khadzu 'diambil'. Pengganti pelaku nā'ib fā'il verbaverba pasif tersebut juga menggunakan pronomina interogatif apa karena pelakunya adalah sesuatu yang tidak berakal. Begitu pula untuk menandai $n \bar{a}$ 'ib $f \bar{a}$ 'il yang berakal juga menggunakan pronominal interogatif sapa, yaitu pada kalimat yang terakhir /wa lā hum yunsharūn ora ditulungi kabeh sapa kaum/ 'Mereka (kaum) semua tidak akan ditolong'. Ná'ib fã $i l$ pada ayat ini adalah adanya tanda yang diwakili oleh wau dan nun (jamak) pada verba ينصرون yang merujuk kepada hum 'mereka'. Namun, pemarkah fungsi fāil dengan BJ sapa ini akan lesap atau tidak disebutkan dalam PTP apabila KT tersebut melekat pada verba imperative. Misalnya:

15.

و إذ قلنا ادخلو إذه القرية فكلو إنها

[wa idz qulnadkhulū hādzihil qaryata fakulū minhā]

Iwa idz qulnā lan nalikane ngendika sapa ingsun/udkhulū mlebuha sira kabeh/hādzihil qaryata ing iki desa (Bait Maqdis)/fakulū maka mangana sira kabeh/minha saking hādzihil qaryah/

'Dan ingatlah ketika Kami berfirman, "Masuklah ke negeri ini (Baitul Maqdis), maka makanlah (dengan nikmat) yang ada di sana ...' (QS 2:58).

Dari contoh di atas dapat diperhatikan PTP pada verba perfek qulnā 'ngendika sapa ingsun' dan verba imperative $u d k h u l \bar{u}$ 'mlebuha sira kabeh' terdapat perbedaan cara menerjemahkan keduanya. Pada verba perfek menggunakan interogatif sapa, tapi pada verba imperative tidak muncul interogatif BJ sapa atau apa. Di samping itu, juga pada verba jamak imperfek untuk persona ke-2 yang biasanya didahului oleh partikel $l \bar{a}$ atau $m \bar{a}$, seperti berikut.

16.

و لا تلبسو ا الحق بالباطل

[wa lā talbisulhaqqa bil bāthili]

Iwa lā talbisū lan aja nyampur sira kabeh/al-haqqa ing perkara kang haq/bil bāthili kelawan perkara kang batil/

'Dan jangan kamu campuraduk kebenaran dan kebatilan'

(QS 2:42)

17.

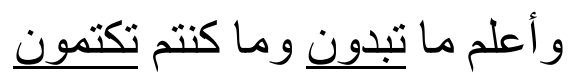


[wa a 'ати mā tubdūna wa mā kuntum taktumūna]

Iwa a'lamu lan pirsa sapa ingsun/mā ing barang/tubdūna kang nglahiraken sira kabeh ing mā/wa mā lan barang/kuntum kang ana sira kabeh/iku taktumūna nyingitaken sira kabeh ing $m \bar{a} /$

'Aku mengetahui apa yang kamu nyatakan dan apa yang kamu sembunyikan' (QS 2:33)

Untuk menandai fungsi $f \bar{a} ' i l$ atau subjek ini juga ditemukan penggunaan pemarkah yang lain, yaitu kata yang menandai pemastian iya (sebagaimana contoh 3). Kata 'iya' ini hanya digunakan untuk pemarkah subjek yang merujuk kepada ism maushul 'conjunctive noun' (Dahdah, 1992:67), seperti pada kalimat berikut.

18.

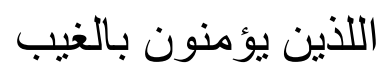

[alladzina yu'minūna bilghaibi]

lalladzinna utawi muta`ayyin iku wong-wong akeh/yu'minūna kang padha percaya iya alladzina/bil ghaibi kelawan barang kang samar/

'Yaitu orang-orang yang percaya kepada yang gaib' (QS 2:3)

\section{Pemarkah Fungsi Objek (maf ūl bih) 'ing'}

Maf ūl bih adalah nomina yang dinashabkan 'kasus akusatif' yang menunjukkan objek penderita (Rajihi, 2011:190) atau nomina berkasus akusatif yang menunjukkan sesuatu dan terletak sesudah fi'l dan fā'il (Ghulayaini, 2005:434; AlMakarim, 2006:151). Fungsi objek dalam bahasa Arab ada dua macam, yaitu objek sharìh 'langsung' dan ghairu sharìh tidak 'langsung' (Ghalayaini, 2005:2:435). Pemarkah fungsi objek langsung (OL) dalam PTP menggunakan preposisi bJ ing 'di'.

\section{a. Pemarkah Objek Langsung (OL)}

Pemarkah ing pada OL ini akan muncul atau digunakan, baik pada objek pertama maupun pada objek kedua. Misalnya,

19.

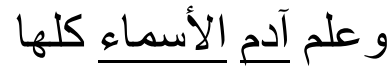

[wa 'allama àdamalasmā'a kullah]

Iwa allama lan mulang sapa Allah/ädama ing Nabi Adam/

al-asmā'a ing arane pira-pira barang/kullahā sekabehane/

'.. dan Allah mengajarkan kepada Adam nama-nama benda semuanya ..' (QS 2:31)

Pemarkah fungsi OL pada contoh di atas menggunakan preposisi bJ ing yang tampak pada kata yang digaris bawah, yaitu kata آدم 'Nabi Adam' adalah fungsi OL pertama dan kata الأسماء 'nama-nama (barang)' adalah fungsi OL kedua. Preposisi bJ ing juga digunakan pada OL, baik sharīh 'mandiri' 
maupun dlamir muttashil 'pronomina persona melekat'. Fungsi OL tersebut dapat ditunjukkan seperti contoh berikut.

20.

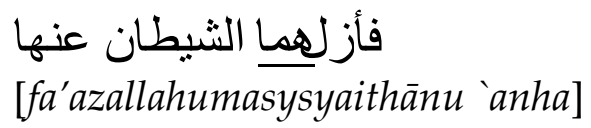

Ifa'azallahuma maka mlesedake ing Adam lan Hawa/sapa asysyaithānu syetan/

'Kemudian keduanya diperdayakan oleh syetan' (QS 2:36)

Pemarkah ing yang lain digunakan pada fungsi objek yang berupa mashdar $m u^{\prime} a w w a l$, yaitu verba imperfek 'mudläri' yang diahului partikel an mashdariyah. Kata seperti itu dalam PTP menggunakan pemarkah gabungan kata tugas dan konjungsi bJ ing yenta 'jikalau', seperti contoh berikut.

21.

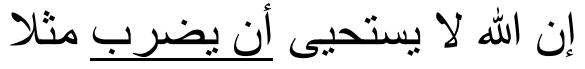

[innallāha lā yastahȳi an yadhriba matsalan]

/innallahz saktemene Allah/iku la yastahyi ora malu sapa Allah lan yadhriba ing yenta gawe sapa Allah/matsalan ing tepa/

'Sesunguhnya Allah tidak segan membuat perumpamaan seekor nyamuk' (QS, 2:26)

\section{b. Pemarkah Objek Tak Langsung (OTL)}

Dalam bahasa Arab OTL adalah objek yang bentuknya berupa frase preposisional. Penambahan kata tugas atau harf jar pada fungsi objek ini disebabkan verba yang digunakan dalam kalimat tersebut adalah verba transitif atau muta addi (Rajihi, 2011:189; Ghulayaini, 2005:28). Akan tetapi, dengan sebab-sebab tertentu kata tugas ini sering disembunyikan atau dibuang (Makarim, 2006:46). Kata tugas 'bantu' yang melekat pada verba transitif ini antara lain dalam PTP menggunakan pemarkah kata tugas BJ ing, marang, ing ndalem, dan saking. Pemarkah-pemarkah fungsi OTL menggunakan kata tugas bJ tersebut banyak ditemukan dalam data. Misalnya adalah:

1. ing 'kepada'

22.

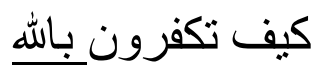

[kaifa takfurūna billāhi]

/kaifa kepriye/takfurūna padha kufur sira kabeh/billāhi ing Allah/

'Bagaimana kamu ingkar kepada Allah' (QS 2:28)

2. marang 'kepada'

23.

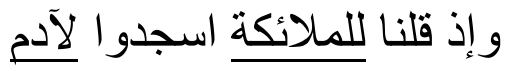

[wa idz qulnā lilmalaikatisjudū li'ādama] 
/wa idz qulnā lan nalikane ngendika sapa ingsun/lilmalāikati marang para Malaikat/usjudū padha sujuda sira kabeh/li'ädama marang nabi Adam/

'Dan (ingatlah) ketika Kami berfirman kepada para Malaikat, sujudlah kamu kepada Adam' (QS, 2:34)

3. ingatase 'di atas'

24.

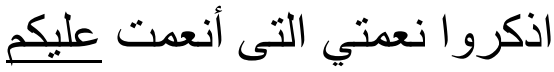

[udzkurū ni mati allati an 'amtu `alaikum]

/udzkurū padha ilinga sira kabeh/ni'matia ing nikmat ingsun/allati kang/an'amtu wus paring nikmat sapa ingsun/ laikum ingatase sira kabeh/

'Wahai Bani Israil, ingatlah nikmatKu yang telah Aku brikan kepadamu..' (QS 2:46).

4. saking 'dari'

كلوا و اشربو ا من رزق الله .

[kulū wasyrabū min rizqillāhi]

/kulū padha mangana sira kabeh/wasyrabū lan padha ngumbea sira kabeh/min rizqillāhi saking peparinge pengeran/

'Makan dan minumlah dari rizqi yang diberikan Allah'

(QS, 2:60)

Juga pada kalimat berikut.

26.

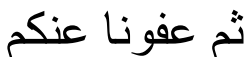

[tsumma 'afaunā 'ankum]

/tsumma 'afaunā mangka kari-karia ngapura sapa ingsun/'ankum saking sira kabeh/

'Kemudian Kami memaafkanmu setelah itu ...' (QS 2:52).

Konstruksi billāhi, li ādama, lil malāikati, ‘alaikum, min rizqillāhi, dan ‘ankum pada kalimat-kalimat di atas adalah bentuk frase preposisional yang berfungsi sebagai OTL. Penerjemahannya ke dalam bahasa sasaran, yaitu pada PTP juga menggunakan kata tugas bJ ing. Konstruksi li ädama diterjemahkan dengan kata tugas 'marang', 'alaikum dengan 'ingatase', sedangkan min rizqillāhi dan 'ankum dengan kata tugas 'saking'.

\section{Pemarkah Fungsi Keterangan}

Keterangan (K) adalah unsur kalimat yang tidak menduduki fungsi S, P, dan $\mathrm{O}$, tetapi mempunyai distribusi yang sama atau sejajar dengan kata keterangan, seperti frasa 'tadi malam' dengan 'tadi' (lihat Ramlan, 2001:163). Hal ini dalam bahasa Arab akan tampak jika memperhatikan segi makna yang dinyatakan, seperti fil ghābati 'di 
dalam hutan'. Dalam bahasa Arab fungsi (K) ini masih disebut juga sebagai maf' $\bar{u} l$ atau objek, yaitu maf ūl fìh, maf ūl liajlih, maf ūl mutlaq 'absolute object' (Al-Khuli, 1991:393). Sementara Asrori (2004:74) dan Dahdah 1991:179) merinci (K) ini menjadi beberapa macam, yaitu: a). Maf ūl fìh 'Keterangan Waktu dan Tempat' (MF); b). Maf ūl Mutalq 'Keterangan Penegas, Frekuensi, dan Model' (MMu); c). Maf ūl li'ajlihi 'Keterangan Maksud/Sebab' (MLi); d) Hāl 'Keterangan Keadaan' (H); dan e). Tamyīz 'Keterangan Pembeda' (KP) atau distinctive (Dahdah, 1992:178).

Sebab bermacam-macamnya pengisi fungsi ini, maka penerjemahannya pun juga berbeda-beda sesuai dengan fungsi $(\mathrm{K})$ itu sendiri, begitu pula kata tugas atau konjungsi yang menyertai penerjemahannya. Contohnya dapat diperhatikan sebagai berikut.

\section{Pemarkah Fungsi Keterangan (Maf $\bar{u} l \mathrm{~F}$ ìh) 'ing' atau 'ingdalem'}

Maf ūl fìh juga biasa disebut dengan zharaf (Al-Khuli, 1999:129-130; Ghulayaini, 2005:465). Maf ūl ini dikatakan zaraf karena wujudnya adalah nomina berkasus akusatif 'manshub' dan mengandung makna $f \bar{\imath}$ ' $\mathrm{di}^{\prime}$ ' yang diujarkan untuk menerangkan waktu atau tempat terjadinya suatu perbuatan. Keterangan atau zharaf ini dalam bahasa Arab juga ada dua maccm, yaitu zaman 'keterangan waktu' dan makan 'keterangan tempat'. Oleh karena itu, dalam PTP di Jawa diartikan sebagai berikut.

\section{a. Keterangan Tempat (Zharaf Makan)}

Zharaf makan adalah nomina yang menerangkan tempat terjadinya suatu perbuatan (Ghulayaini, 2005:465). Contohnya adalah:

27.

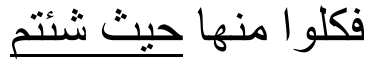

[fakulū minhā haitsu syi'tum]

Ifa kulū mangka mangana sira kabeh/minhē saking hadzihilqaryatal haitsu syi'tum ingdalem endi karepe sira kabeh/

'Maka makanlah dengan nikmat yang ada di sana sesukamu' (QS 2:58)

28.

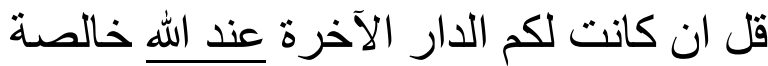

[qul in kānat lakumuddārul ākhiratu ‘ndllāhi khālishatan]

Iqul dawuha sira Muhammad/in kānat lamun ana/iku lakum kaduwe sira kabeh/apa addārul akhiratu desa akhirat/'indallahi ingdalem ngarsane Allah/khālishatan hale murni/

'Katakanlah (Muhammad), Jika negeri akhirat di sisi Allah, khusus untukmu saja bukan untuk orang lain' (QS 2:94)

\section{b. Keterangan Waktu (Zharaf Zaman)}

Zharaf zaman adalah nomina yang menerangkan waktu terjadinya sutu perbuatan (Ghulayaini, 2005:465). Contohnya:

29.

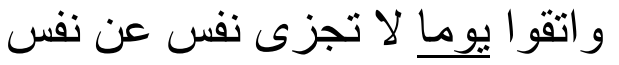


[wattaqū yauman lā tajzī nafsun 'an nafsin]

/wattaqū padha wedia sira kabeh/yauman ing dina/lā tajzì kang ora bisa males/apa nafsun awak-awakan/an nafsin sangking awak-awakan kang weneh/

'Dan takutlah kamu pada hari (ketika) tidak seorang pun dapat membela orang lain' (QS, 2:48)

30.

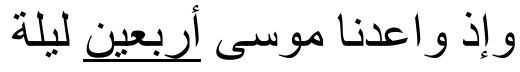

[wa idz wā ‘adnā mūsa arba ina lailatan]

/wa'idz $w \bar{a}{ }^{\prime} a d n \bar{a}$ lan nalikane paring janjian sapa ingsun/mūsa ing Nabi Musa/arba`ina ingdalem patang puluh/ apane lailatan wengine/

'Dan (ingatlah) ketika Kami menjanjikan kepada Musa empat

puluh malam' (QS, 2:51)

Kata-kata yang digaris bawah pada contoh kalimat (30) yauman 'hari' dan (31) arba ìna lailatan ' 40 malam' di atas merupakan keterangan yang menunjukkan waktu atau saat yang digunakan untuk menjelaskan terjadinya peristiwa.

\section{Pemarkah Fungsi Keterangan (Maf ūl Mutlaq) 'kelawan'}

Maf ūl mutlaq adalah penyebutan nomina mashdar 'dasar' setelah verba yang sama dengan nomina tersebut yang dimaksudkan untuk menegaskan, menjelaskan jumlahnya atau menerangkan macamnya atau sebagai ganti penggunaan verbanya (Rajihi, 2011:216; Ghulayaini, 2005:457).

31.

حتى نرى الله جهرة

[hattā narallāha jahratan]

/hattā narā hingga sumerap kula/Allāha ing Gusti Allah/ jahratan kelawan ngiding/

'... sebelum kami melihat Allah dengan jelas' (QS, 2:55)

32.

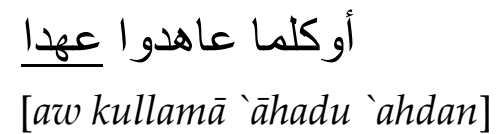

/awakullamā anata nalikane/'āhadu janjian sapa Bani Israel/ ‘hdan kelawan janjian temenan/

'... Mengapa setiap kali mereka mengikat janji...' (QS, 2:100)

Jika diperhatikan kata jahratan (32) merupakan bentuk mashdar dari verba jahara 'membaca dengan keras' atau 'melihat dengan mata' yaitu 
memberikan pengertian penegasan. Menurut Darwisy (2011:106) akustatifnya nomina ini juga dapat dianggap sebagai $h \bar{a} l$. Demikian pula nomina ‘ahdan dalam ayat merupakan bentuk mashdar dari verba 'āhada 'janji' atau bermakna $a$ 'th $\bar{u}$ 'memberi' (Darwisy, 2011:148) sehingga bentuk akusatifnya nomina juga dapat diangap sebagai maf $\bar{u} l$ muthlaq.

\section{Pemarkah Fungsi Keterangan (Maf'ūl Liajlih) 'kerana'}

Maf ūl Liajlih adalah nomina mashdar yang disebutkan untuk menerangkan sebab terjadinya suatu pekerjaan (Ghulayaini, 2005:462) dan bersamaan waktu kejadian tersebut dilakukan oleh subjek (Rajihi, 2011:224).

33.

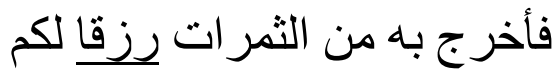

[faakhraja bihi minatstsamārati rizqan lakum]

/fa'akhraja maka ngetoake ay alladzinna/bihī kelawan banyu/minats-tsamarāti saking pira-pira werna/rizqan kerana ngrezkeni/lakum maring sira kabeh/

'.lalu Dia hasilkan dengan (hujan) itu buah-buahan sebagai rizki untukmu' (QS, 2:22)

34.

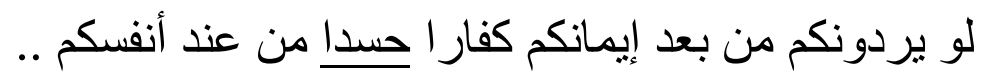

[law yaruddūnakum min ba'di ìmānikum kuffäran hasadan min 'indi anfusikum]

/law yaruddūnakum menawa-menawa bisa ambaleaken sapa katsīr ing sira kabeh/min ba'di ìmānikum saking sakwise iman sira kabeh/kuffäran hale dadi kafir kabeh/hasadan kerana drengki kang timbul/min ‘ndi anfusihim saking awak deweke katsìrl

'...sekiranya mereka dapat mengembalikan kamu setelah kamu beriman menjadi kafir kembali, karena rasa dengki dalam diri mereka ...' (QS, 2: 109)

Kata rizqan 'ngrezekeni' adalah nomina yang menjelaskan terjadinya peristiwa 'hujan' pada contoh (34) dan hasadan 'drengki' menjelaskan terjadinya sifat 'drengki' atau 'dengki' pada contoh (35), karena mereka menginginkan orangorang tersebut menjadi kafir.

\section{Pemarkah Fungsi Keterangan (Al-Hāl) 'halih'}

Al-Hāl adalah kata nomina yang disebutkan untuk menjelaskan keadaan subjek $f \bar{a} \backslash i$ atau objek maf $\bar{u} l$ ketika terjadinya suatu pekerjaan (Al-Khuli, 1999:49; Ghulayaini, 2005:486). Dalam PTP nomina tersebut tersebut dengan kata 'halih' sebagai berikut.

35.

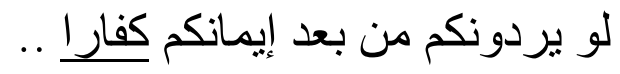

[law yaruddūnakum min ba'di ìmanikum kuffāran] 
/law yaruddūnakum menawa-menawa bisa ambaleaken sapa katsir ing sira kabeh/min ba`di ìmānikum saking sakwise iman sira kabeh/kuffäran halih dadi kafir kabeh/

'...sekiranya mereka dapat mengembalikan kamu setelah kamu beriman menjadi kafir kembali..' (QS, 2: 109)

Mashdar atau nomina kuffāran dalam ayat ini merupakan keterangan yang menjelaskan keadaan sesorang yang menjadi tidak beriman lagi kepada Allah, padahal mereka sudah beriman sebelumnya. Demikian juga pada contoh sebelumnya, yaitu mashdar jahratan '(dengan) jelas' (contoh 32) adalah keterangan yang menjelaskan keadaan masyarakat Bani Israel yang tidak mau percaya akan dakwah Nabi Musa sebelum dapat melihat Allah secara nyata di hadapan mereka (Musthafa, tt:17).

\section{Pemarkah Fungsi Keterangan Tamyīz (Pembeda) 'apane'}

Tamyīz adalah nomina taktentu (nakirah) yang disebutkan untuk mejelaskan maksud yang sebenarnya dari nomina yang sebelumnya (Rajihi, 2011:257). Tamyiz ini jika tidak disebutkan, maka kalimat tersebut dapat bermakna macam-macam. Dalam PTP nomina ini didahului dengan pemarkah interogatif apane 'apanya'. Nomina tamyīz dapat diperhatikan pada ayat-ayat berikut.

36.

..... ماذا أر اد الله بهذا مثنلا ....

[ $m \bar{a} d z \bar{a}$ aradallāhu bihādzā matsalan]

Imā $d z \bar{a}$ utawi apa/iku arādallāhu ngersaaken sapa Allah/bihādzā kelawan iki/apane matsalan teladhane/

'.. Apa yang Allah inginkan dengan perumpamaan ini?

(QS, 2:26)

\section{Kesimpulan}

Tradisi pesantren di Jawa memiliki keunikan tersendiri dalam usaha memahami isi kitab-kitab yang berbahasa Arab. Kitab-kitab tersebut ditulis oleh para mujahid Islam terdahulu. Usaha tersebut adalah menerjemahkan kitab-kitab klasik tersebut ke dalam bahasa setempat, salah satunya adalah penerjemahan ke dalam bahasa Jawa. Pada penerjemahan ini dilakukan tidak hanya pengalihan arti kata perkata dari bahasa Arab ke dalam bahasa Jawa, sekaligus juga dilakukan penerjemahan satuan-satuan gramatikalnya.

Satuan gramatikal yang dimaksud adalah fungsi unsur kalimat yang ditandai dengan kata-kata tertentu. Kata-kata ini diselipkan pada penerjemahan kata, baik pada kalimat nominal maupun kalimat verbal. Pada kalimat nominal, fungsi subjek ditandai utawi sebagai sesuatu yang menjadi pokok pembicaraan, fungsi predikat ditandai dengan $i k u$ sebagai unsur kalimat yang menjelaskan subjek. Pada kalimat verbal, fungsi subjek ditandai dengan sapa (orang) dan apa (barang) sebagai sesuatu yang melakukan pekerjaan, sedangkan fungsi objek ditandai dengan ing sebagai 
unsur kalimat yang menderita karena tindakan subjek yang tersebut pada predikat. Fungsi keterangan ditandai dengan ingatase, kelawan, kerana sebagai unsur kalimat yang dimaksudkan untuk menerangkan atau menjelaskan predikat. Sementara hal dan tamyiz ditandai dengan halih dan apane sebagai pelengkap yang menjelaskan keadaaan ataupun untuk membatasi pengertian kalimat yang dimaksud.

Penempatan pemarkah-pemarkah gramatika pada PTP Arab-Jawa ini selalu mengikuti struktur gramatika bahasa Arab sehingga hasil terjemahan PTP dalam bahasa Jawa ini juga terdapat nuansa bahasa Arab. Dengan demikian PTP dapat dikatakan sebagai interferensi atau pengaruh bahasa Arab ke dalam bahasa Jawa, khususnya dalam kehidupan pesantren di Indonesia. Akan tetapi, pengaruh yang didapat dari pemahaman terhadap pemarkahan satuan gramatika ini kiranya dapat dirasakan menfaatnya oleh pembelajar untuk dapat memahami dan menguasai isi kitab-kitab klasik melalui struktur gramatika bahasa Arab sekaligus penerjemahannya ke dalam bahasa Jawa.

\section{DAFTAR PUSTAKA}

Asrori, Imam. 2004. Sintaksis Bahasa Arab: Frasa-Klausa-Kalimat. Malang: Penerbit Misykat.

Ad-Dahdah, Antoine. 1999. Mu`jamul I’rab fi An-Nahwiy Al-`Arabiy: Qawa`id wa Tathbiqat wa Faharis. Lebanon: Maktabah Lubnan

1992. Mu`jamu Qaewa'id Al-'Arabiyyah Al-'Alamiyyah: 'ArabiyIngliziy. Lebanon: Maktabah Lubnan.

Ad-Darwisy, Muhyiddin. 2011. I'rabul Qur'anil Karim. Jilid I. Beirut: Mathba ah Dar Al-Katsir.

Dhofier, Zamakhsyari. 1982. Tradisi Pesantren: Studi tentang Pandangan Hidup Kyai: Jakarta: LP3ES.

Drewes, NY. R. 1997. Buletin Humaniora No. VI. 'Penerjemahan sebagai Dialog Antar Budaya. Beberapa Catatan Mengenai Teori dan Metode Penerjemahan'. Yogyakarta: fakultas Sastra UGM.

Al-Ghalayainiy, Musthafa. 2005. Jamiuddurus al-'Arabiyah: Mausu'ah fi Tsalatsati Ajza'. Cairo: Dar Al-Hadits.

Al-Khuli, Muhammad Ali. 1991. A Dictionary of Theoretical Linguistics. Cetakan I. Lebanon: Maktabah Lubnan.

Al-Makarim, Ali Abu. 2007. Al-Jumlah Al Filiyah. Cetakan I. Cairo: Muassasah AlMukhtar.

Masrukhi, Moh. 2003. "Pengaruh Konstruksi Frase Bahasa Arab pada Konstruksi Frase Bahasa Jawa dalam Terjemahan Kitab-Kitab Klasik". Thesis. Yogyakarta: Sekolah Pascasarjana Unibersitas Gadjah Mada.

Musthafa, Bisyri. TT. Al-Ibriz: Lima`rifati Tafsiril Qu'anil Karim Billughatil Jawiyyah. Juz 1. Kudus: Penerbit Menara Kudus.

Ar-Rajihi, 'Abduh. 2011. At-Tathbiq An-Nahwiy. Riyadh: Maktabah Al-Ma`arif. 
Ramlan, M. 1987. Sintaksis. Yogyakarta: CV Karyono.

1980. Kata Depan atau Preposisi dalam Bahasa Indonesia. Yogyakarta: UP Karyono.

Van Bruinessen, Martin. 1999. Kitab Kuning, Pesantren dan Tarekat. Bandung: Mizan. 